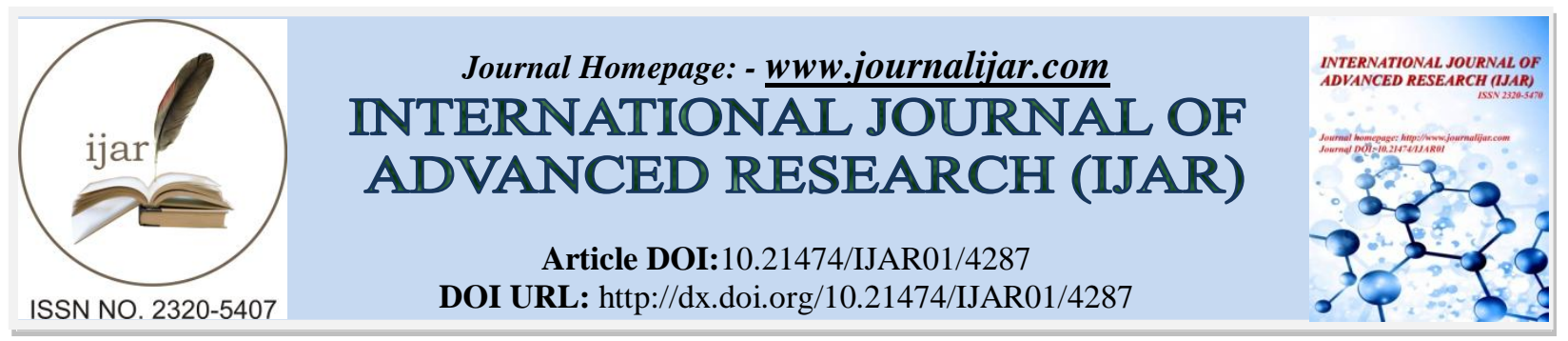

RESEARCH ARTICLE

\title{
BRAND COGNIZANCE AND CUSTOMER PREFERENCES FOR FMCG PRODUCTS IN RURAL MARKET: A SPECULATIVE STUDY ON THE RURAL MARKET OF JAIPUR REGION.
}

\author{
Praveen Saiwal ${ }^{1}$ and Dr. Kavaldeep Dixit ${ }^{2}$. \\ 1. Research Scholar - IIS University, Jaipur, Rajasthan. \\ 2. Vice Principal, International School of Informatics and Management, Jaipur.
}

\section{Manuscript Info}

(..........................

Manuscript History

Received: 28 March 2017

Final Accepted: 30 April 2017

Published: May 2017

Key words:-

Brand Awareness, Rural Area,

Consumer Goods, FMCG, Customer

\section{Abstract}

The purpose of this study is to examine the brand awareness in rural area and to study the interest of consumers in branded products of Fast Moving Consumer Goods (FMCG). The brand cognizance (awareness) is showing increasing tendency everywhere and Amber region of Jaipur district of Rajasthan State is not an exception to it. To examine the validity of this general statement that is being discussed day in and day out by the researcher, market managers, producers, consumers, advertisers, etc., Research Paper on brand awareness in rural area of Fast Moving Consumer Goods in Amber Region of Jaipur district of Rajasthan state is taken up.

Copy Right, IJAR, 2017,. All rights reserved.

\section{Introduction:-}

\section{Fast Moving Consumer Goods (FMCG):-}

The Fast Moving Consumer Goods (FMCG) sector is a corner stone of the Indian economy. It is an important contributor in India's GDP. It is the fourth largest sector of the Indian economy. The FMCG market is estimated to treble from its current figure in the coming decade. Penetration levels as well as per capita consumption of most product categories like jams, toothpaste, skin care and hair wash in India are low, indicating the untapped market potential. The growing Indian population particularly the middle class and the rural segments, presents an opportunity to makers of branded products to convert consumers to braded products. The Indian market with its vast size and demand base offers huge opportunity for investment. Indian consumer market has a large consuming class with 41 percent of India's middle-class and 58 percent of the total disposable income.

Fast Moving Consumer Goods (FMCG) satisfies the elemental and day-to-day household needs other than grocery, ranging from packaged foodstuff, dairy products, cooking oil, bread, butter, cereals, beverages like tea \& coffee, pharmaceuticals, confectionery, biscuits, glassware, stationary items, watches, toiletries, detergents, shampoos, skin care products, cosmetics, toothpaste, dish washing liquid, shaving cream, razor, batteries, shoe polish, energy drinks, soft drinks, clothing, furniture and household accessories to electronic goods like cell phones, laptops, computers, digital cameras etc. that are usually categorized as Fast Moving Consumer Electronics or FMCEs.

A major portion of the monthly budget of each household is spent on FMCG products. The introduction of sachets made rural people who are traditionally not accustomed for bulk purchase, to buy branded FMCG products like Rs1/- shampoo, nut powders, oils, detergents, cleaning powders \& liquids, tooth pastes, etc. in rural shops. This changed the pattern of buying from traditional products to branded products. 
The Fast Moving Consumer Goods (FMCG) sector touches every aspect of human life. The FMCG producers have realized that there is ample opportunity for them to enter into the rural market. Today we notice this shift towards branded FMCGs in rural areas as a result of Socio Economic \& Political changes in the last 5 years. This has made rural areas more viable markets even compared to urban areas. The Socio Economic and Political changes contributed to a great extent for changes in the life styles of countryside people who patronized branded FMCG products. The Government policies to promote education in rural areas enhanced their brand awareness due to the presence of at least one higher education pursuing student in their family or neighboring family. The different Government policies are also being helpful for rural people contributed in enhancing people's income followed by a change in their lifestyles resulted in patronizing the branded products.

According to the National Council of Applied Economic Research (NCAER) about 70 per cent of Indian population living in villages, India has perhaps the largest potential rural market in the world. It has as many as 47,000 haats (congregation markets), compared to 35,000 supermarkets in the US and of the total FMCGs demand in India, nearly 53 per cent comes from the rural market. At present Indian FMCG sector is worth Rs. 1300 billion and expected to be around a whopping value of Rs. 4000 to Rs. 6000 billion by 2020. Henceforth FMCG and its closest companion Retail sector, both are likely to create most of the jobs in India in the coming years primarily in functions like marketing, sales, advertising, supply chain, logistics, human resources, product packaging and development, finance, operations, general management, supervising and so on.

\section{Brand Awareness and Customer Preferences:-}

Brand awareness is the degree of familiarity among consumers about the life and availability of the product. It is measured as ratio of niche market that has former knowledge of brand. Brand awareness includes both brand recognition as well as brand recall. Brand recognition is the ability of customer to recognize prior knowledge of brand when they are asked questions about that brand or when they are shown that specific brand, While brand recall is the potential of customer to recover a brand from his memory when given the product class/category, needs satisfied by that category or buying scenario as a signal. In other words, it refers that consumers should correctly recover brand from the memory when given a clue or he can recall the specific brand when the product category is mentioned. It is generally easier to recognize a brand rather than recall it from the memory.

Consumer preferences are defined as the subjective (individual) tastes, as measured by utility, of various bundles of goods. They permit the consumer to rank these bundles of goods according to the levels of utility they give the consumer. Note that preferences are independent of income and prices. Ability to purchase goods does not determine a consumer's likes or dislikes. This is used primarily to mean an option that has the greatest anticipated value among a number of options. Preference and acceptance can in certain circumstances mean the same thing but it is useful to keep the distinction in mind with preference tending to indicate choices among neutral or more valued options with acceptance indicating a willingness to tolerate the status quo or some less desirable option.

\section{Review of Literature:-}

The two important measure of brand awareness is brand recognition and recall. (Hoyer and Brown, in 1990,) Kapferer, in 1988 says "top of mind awareness is critical as it captures the 'consideration set' in a givenpurchase situation. (Laurent, Kapferer and Roussel, 1995) Study on recall of pictorial advertisements as compared to nonpictorial advertisements indicate how much more effective they are rural consumers as compared to urban consumers. (Velayudhan, 2002) In some studies, brand preference has been equated with brand loyalty (e.g., Rundle-Thiele and Mackay 2001). In other studies, it has been evaluated as a precursor to brand loyalty (e.g., Odin et al. 2001). Ben-Akiva et al. (1999) define preferences as "comparative judgments between entities." Additional reasons (other than promotions) why consumers may purchase other brands despite a stated brand preference include a desire to try and learn more about different brands in the category; changing needs or situations; variety seeking; and changes in the available alternatives due to new products or improvements to existing products (Coulter et al. 2003). Alba and Hutchison (1987) propose that experts are more likely to search for new information because (a) expertise increases awareness of the existence of potentially acquirable information and (b) familiarity reduces the cost of information acquisition. Schmidt andSpreng (1996) further postulate that knowledge increases the perceived ability to search and therefore shoulddecrease the perceived costs of search. Greater knowledge has been shown to be positively related to increased involvement with a category (e.g., Raju et al. 1995). Dunn et al. (1978) viewed advertising from its functional perspectives; Morden (1991) is of the opinion that advertising is used to establish a basic awareness of the product. Those views of Etzel et al. (1997) coincide with the simple but allembracing definitions of Davies (1998) and Arens (1996). Aaker (2000) regarded brand awareness as a remarkably 
durable and sustainable asset. Yee and Young (2001), aimed to create awareness of high fat content of pies, studied consumer and producer awareness about nutrition labeling on packaging.

Chen (2001) expressed a different thought on brand awareness that it was a necessary asset but not sufficient forbuilding strong brand equity. Beverland (2001) analyzed the level of brand awareness within the New Zealand market for zespri kiwi fruit.

\section{Objectives Of The Research Paper:-}

The objective of the study is to understand the buying perception of the rural consumer towards FMCG Products. For this, the objectives of the Research Work are as under:

- To study the perception of the rural consumer towards FMCG products

- To examine the brand preference and awareness of rural consumer towards FMCG products to study the attributes of brand preference.

- To study the impact of media on brand cognizance \& preferences.

\section{Hypothesis Of The Study:-}

The main aim of the study is to test the following hypothesis:

$\mathbf{H}_{1}$ : $\quad$ There is significant difference between male and female attitudes towards brand

$\mathbf{H}_{2}: \quad$ There is significant difference among different age groups attitude towards brand.

$\mathbf{H}_{3}$ : There is significant difference among different Academic Qualification attitudes towards brand

$\mathbf{H}_{4}$ : $\quad$ There is significant difference among different income group attitudes towards brand.

$\mathbf{H}_{5}$ : There is significant difference among male and female attitudes towards brand awareness throughMedia.

Scope And Need For The Study:-

FMCG products are substantially used to enhance and protect the health and physical appearance and also the dignity of the people among their counterparts. The spending on FMCG products especially in the rural areas is showing an increasing tendency in the last 5 years. This is due to increase in income levels, fascination towards urban culture, good connectivity to near- by towns \& cities, improvement in sanitary conditions, beauty awareness among teenagers of rural areas emulating their counterparts in the urban areas led to the increased usage of FMCG products particularly beauty \& health care products in this region. With this backdrop the brand awareness in rural areas with reference to FMCG products is thought of. The study is confined only to Jaipur Region of Rajasthan State. It is believed that the findings in this region are fairly representative of the other parts of the State and the lifestyle \& other parameters are not much different from what exist in the area of survey.

\section{Research Methodology:-}

The methodology of the study is based on the primary as well as secondary data. The study depends mainly on the primary data collected through a well-framed and structured questionnaire to elicit the well-considered opinions of the respondents. The study is confined to 10 villages of Amber Region. Amber Region of Jaipur District is basically a rural oriented region and about 70 percent of population living in villages. Amber Region comprises of 197 villages. Due to paucity of time and financial constraints 10 villages of namely Achrol, r, Kant, Nangal, Chandwaji, govindpura, Jaitpura, Lakher and chandwas are chosen for survey adapting simple random sampling technique. In all 100 respondents are chosen from different age groups classifying them on the basis of literacy with the help of structured \& unstructured interviews \& discussions with these respondents the information for this survey is gathered.

The information gathered through the questionnaires will be analyzed with the help of SPSS software by using the Tabular Presentation, $t$ test and Analysis of Variance (ANOVA).

Limitations of the Study:-

Three limitations have been identified in this study. First, the research work covers only 10 villages of Amber region. Second, the respondents don't want to disclose their personal information and their perception about the organization to the researchers. Third, the sample size do not ensure representative and conclusive finding and finally, a more robust analysis is needed to reach a strong conclusion. 
Findings and interpretations:-

Demographic Profile of Respondents:-

Table 8.1:-The Demographic Profile of Respondents

\begin{tabular}{|l|c|c|}
\hline Details & Frequency (N) & Percentage (\%) \\
\hline Gender & \multicolumn{2}{|c|}{} \\
\hline Male & 50 & $50 \%$ \\
\hline Female & 50 & $8 \%$ \\
\hline Age & 8 & $25 \%$ \\
\hline Below 20 & 25 & $40 \%$ \\
\hline Between 20-30 & 40 & $27 \%$ \\
\hline Between 30-40 & 27 & $34 \%$ \\
\hline Above 40 & \multicolumn{2}{|c|}{} \\
\hline Academic Qualification & 34 & $40 \%$ \\
\hline Up to School & 40 & $22 \%$ \\
\hline Up to Graduate & 22 & $4 \%$ \\
\hline Up to Post Graduation & 4 & $24 \%$ \\
\hline Professional & & $21 \%$ \\
\hline Monthly Income & 24 & $22 \%$ \\
\hline 5,000-10,000 & 21 & $33 \%$ \\
\hline 10,000-15000 & 22 & $25 \%$ \\
\hline Above 15000 & 33 & $37 \%$ \\
\hline Dependant Respondent (No Income Group) & & $38 \%$ \\
\hline Types of Products Prefers & 25 & \\
\hline Prefer Brand & 37 & \\
\hline Prefer Non Brand & 38 & \\
\hline Prefer Quality of Product over Brand & & \\
\hline
\end{tabular}

Brand Awareness in Rural Market:-

Table 8.2:-Brand Awareness in Rural Market

\begin{tabular}{|c|c|c|c|c|c|c|c|c|c|}
\hline Shampoo & $\mathbf{( \% )}$ & Washing & $\mathbf{( \% )}$ & Soap & $\mathbf{( \% )}$ & Tea & $(\%)$ & Toothpaste & $(\%)$ \\
\cline { 3 - 9 } & & Powder & & & & & & & \\
\hline Garnier & 64 & Nirma & 78.9 & Lux & 95.8 & Taj Mahal & 78 & Colgate & 97 \\
\hline Chik & 67 & Wheel & 85.3 & Dettol & 82.1 & Tata Tea & 90 & Pepsodent & 91 \\
\hline Vatika & 72 & Surf excel & 70.5 & Lifebuoy & 89.5 & Maharani & 50 & Babool & 65 \\
\hline Lux & 73 & Rin & 87.4 & Rexona & 56.8 & Agni Tea & 65 & Cibaca & 61 \\
\hline Pantene & 80 & Arial & 53.7 & Centhol & 65.3 & Brooke bond & 61 & Dabarlal & 67 \\
\hline Sunsilk & 81 & Tide & 75.8 & Dove & 52.6 & Red label & 62 & Vicco & 46 \\
\hline Clinic plus & 87 & Hanko & 41.1 & Hamam & 62.1 & LiptonTaza & 44 & Close-up & 82 \\
\hline Average & $\mathbf{7 5}$ & Average & $\mathbf{7 0 . 3}$ & Average & $\mathbf{7 2 . 0 2}$ & Average & $\mathbf{6 4}$ & Average & $\mathbf{7 3}$ \\
\hline
\end{tabular}

\section{Interpretation:-}

It has been concluded from the above table that the average awareness of the respondents in therural market is $75 \%$, in case of shampoo, in case of washing powder the average awareness of the respondents is $70.3 \%$, in case of soap the average awareness of the respondent is $72.02 \%$, in case of Tea it is $64 \%$ and in case of Toothpaste the average awareness is $73 \%$.

\section{Brand Preference in Rural Market:-}

Table 8.3:- Brand Preference in Rural Market.

\begin{tabular}{|c|c|c|c|c|c|c|c|c|c|c|c|c|c|c|c|}
\hline \multicolumn{3}{|c|}{ Shampoo } & \multicolumn{3}{|c|}{ Washing powder } & \multicolumn{3}{|c|}{ Soap } & \multicolumn{4}{|c|}{ Tea } & \multicolumn{3}{|c|}{ Tooth Paste } \\
\hline 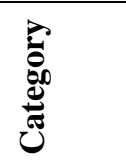 & 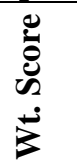 & 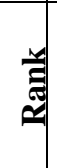 & 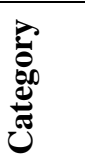 & 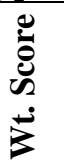 & 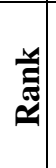 & 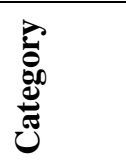 & 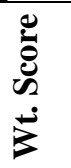 & שֶ & 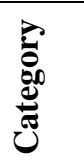 & & 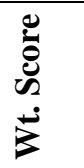 & & 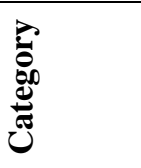 & 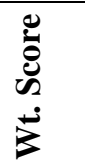 & 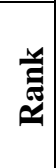 \\
\hline Panten & 3.4 & 1 & Surf & 3.4 & 1 & Dettol & 3.6 & 1 & Tata & ea & 4.07 & & Col & 4.21 & 1 \\
\hline
\end{tabular}




\begin{tabular}{|c|c|c|c|c|c|c|c|c|c|c|c|c|c|c|}
\hline e & & & & & & & & & & & \\
\hline Vatika & 3.05 & 2 & Rin & 3.08 & 2 & Lux & 3.59 & 2 & Taj mahal & 3.16 & 2 & Pepsodent & 3.6 & 2 \\
\hline Lux & 3.02 & 3 & Wheel & 3.02 & 3 & Lifebuoy & 3.29 & 3 & Brook bond & 3 & 3 & Dabar lal & 2.51 & 3 \\
\hline Garnier & 3.01 & 4 & Arial & 2.76 & 4 & Centhol & 2.65 & 4 & Agni tea & 2.84 & 4 & Babool & 2.49 & 4 \\
\hline Chik & 2.53 & 5 & Nirma & 2.75 & 5 & Rexona & 2.31 & 5 & Maharani & 2.16 & 5 & Cibaca & 2.21 & 5 \\
\hline
\end{tabular}

Interpretation : From the above table we can see that in case of the shampoo category the respondents give $1^{\text {st }}$ rank to pantene, $2^{\text {nd }}$ to Vatika, $3^{\text {rd }}$ to Lux, $4^{\text {th }}$ to Garnier and $5^{\text {th }}$ to Chik. In case of washing powder the respondent's gives $1^{\text {st }}, 2^{\text {nd }}, 3 \mathrm{rd}$, 4th, 5th rank to Surf, Rin, Wheel, Arial, Nirma respectively. In case of soap the respondents give $1^{\text {st }}$ to Dettol, $2^{\text {nd }}$ to Lux, $3^{\text {rd }}$ to Lifebuoy, $4^{\text {th }}$ to Centhol and $5^{\text {th }}$ to Rexona. In case of Tea the respondents give $1^{\text {st }}$ rank to Tata tea, $2^{\text {nd }}$ to Taj Mahal, $3^{\text {rd }}$ to Brook Bond, $4^{\text {th }}$ to Agni and $5^{\text {th }}$ to Maharani tea. In case of category toothpaste the respondents give $1^{\text {st }}$ to Colgate, $2^{\text {nd }}$ to Pepsodent, $3^{\text {rd }}$ to Dabarlal, $4^{\text {th }}$ to Babool and last rank to the Cibaca.

\section{Attributes of Brand Preference:-}

Table 8.4:- Attributes of Brand Preference in Rural Market.

\begin{tabular}{|c|c|c|}
\hline Factors & Weighted Score & Rank \\
\hline Quality & 5.72 & 1 \\
\hline Price & 5.31 & 2 \\
\hline Easy availability & 4.34 & 3 \\
\hline Family liking & 4.16 & 4 \\
\hline Advertisement & 3.00 & 5 \\
\hline Variety & 2.76 & 6 \\
\hline Credit & 2.66 & 7 \\
\hline
\end{tabular}

\section{Interpretation:-}

From the above table no 8.4 it is inferred that the respondents give $1^{\text {st }}$ rank to Quality, $2^{\text {nd }}$ toPrice, $3^{\text {rd }}$ to Easy Availability, $4^{\text {th }}$ to Family Liking, $5^{\text {th }}$ to Advertisement, $6^{\text {th }}$ to Variety $\& 7^{\text {th }}$ rank to Credit Facility Allowed by the Shop-keeper for brand preference.

\section{Interpretation Throgh Inferential Analysis:-}

To analyze the impact of brand across demographics, the following hypothesis has been tested through $\mathrm{T}$ - test and Anova.

Gender Vs Brand:-

$\mathbf{H}_{\mathbf{0}}$ : There is no significant difference between male and female attitude towards brand.

$\mathbf{H}_{\mathrm{A}}$ : There is significant difference between male and female attitudes towards brand.

Table 9.1:-(A) : T-Test : Test of Significance Between Brand Preference \& Gender of The Respondents

\begin{tabular}{|l|l|l|l|l|}
\hline Gender of the Respondents & N & Mean & Std. Deviation & Std. Error Mean \\
\hline Male & 50 & 1.72 & .757 & .107 \\
\hline Female & 50 & 2.04 & .781 & .111 \\
\hline
\end{tabular}

Table 9.1 (B):-T-Test : Test of Significance Between Brand Preference \& Gender of The Respondents.

\begin{tabular}{|l|l|l|l|l|l|l|l|}
\hline & & Levene's & Test for & \multicolumn{1}{l|}{ t-test } & \multicolumn{1}{l|}{ for } \\
\hline & & Equality of Variances & \multicolumn{2}{|c|}{ Equality of Means } \\
\hline \multirow{2}{*}{ Attitude } & Equal variances assumed & F & .328 & Sig. & t & d.f. & Sig. (2-tailed) \\
\cline { 2 - 8 } & Equal variances not assumed & & .568 & .208 & 98 & .040 \\
\hline
\end{tabular}

\section{Interpretation:-}

The above table indicate that Significant value is 0.040 which is less than $(\mathrm{P}<0.05)$, hence thenull hypothesis is rejected and we may conclude that there is a significant difference between male and female attitude towards brand. 


\section{Age Vs Brand:-}

$\mathbf{H}_{\mathbf{0}}$ : There is no significant difference among different age groups attitude towards brand.

$\mathbf{H}_{\mathrm{A}}$ :There is significant difference among different age groups attitude towards brand.

Table 9.2:- Annova : Test of Significance Between Brand Preference \& Different Age of Respondents Age of the Respondents:-

\begin{tabular}{|l|l|l|l|l|l|}
\hline Variable & Sum of Squares & D.f. & Mean Square & F & Sig. \\
\hline Between Groups & 4.883 & 3 & 1.628 & 2.769 & .046 \\
\hline Within Groups & 56.247 & 96 & .588 & & \\
\hline Total & 61.310 & 99 & & & \\
\hline
\end{tabular}

\section{Interpretation:-}

The above table indicate that Significant value is 0.046 which is less than $(\mathrm{P}<0.05)$, hence thenull hypothesis is rejected. There is a significant difference between different age groups attitudes towards brand

\section{Academic Qualifications Vs Brand:-}

$\mathbf{H}_{\mathbf{0}}$ : There is no significant difference among different Academic Qualification attitudes towards brand

$\mathbf{H}_{\mathbf{A}}$ : There is significant difference among different Academic Qualification attitudes towards brand

Table 9.3:-Annova : Test of Significance Between Brand Preference \&

Academic Qualification of Respondents:-

Academic Qualifications:-

\begin{tabular}{|l|l|l|l|l|l|}
\hline Variable & Sum of Squares & Df & Mean Square & F & Sig. \\
\hline Between Groups & 6.626 & 3 & 2.209 & 3.932 & .011 \\
\hline Within Groups & 53.934 & 96 & .562 & & \\
\hline Total & 60.560 & 99 & & & \\
\hline
\end{tabular}

\section{Interpretation:-}

The above table indicate that Significant value is 0.011 which is less than $(\mathrm{P}<0.05)$, hence thenull hypothesis is rejected. Thus, there is a significant difference between different Academic Qualification attitudes towards brand.

\section{Monthly Income Vs Brand:-}

$\mathbf{H}_{\mathbf{0}}$ : There is no significant difference among different income group attitudes towards brand.

$\mathbf{H}_{\mathrm{A}}$ : There is significant difference among different income group attitudes towards brand.

Table 9.4:- Annova : Test of Significance Between Brand Preference \& Monthly Income of Respondents Monthly Income:-

\begin{tabular}{|l|l|l|l|l|l|}
\hline Variable & Sum of Squares & Df & Mean Square & F & Sig. \\
\hline Between Groups & 1.826 & 3 & .609 & .995 & .399 \\
\hline Within Groups & 58.734 & 96 & .612 & & \\
\hline Total & 60.560 & 99 & & & \\
\hline
\end{tabular}

\section{Interpretation:-}

The above table indicate that Significant value is 0.399 which is greater than $(\mathrm{P}>0.05)$, hencethe null hypothesis is accepted. There is no significant difference between different income group attitudes towards brand. Thus, we may conclude that only income does not affect the attitude towards brand.

\section{Correlation between Media and Brand Preference:-}

$\mathbf{H}_{\mathbf{0}}$ : There is no significant relation between Media and Brand Preference.

$\mathbf{H}_{\mathbf{A}}$ : There is significant relation between Media and Brand Preference.

Table 9.5:-Pearson Correlation: Correlation Analysis Between Brand Preference \& Different Media.

\begin{tabular}{|c|c|c|}
\hline & \multicolumn{2}{|c|}{ Brand Preference Role of Media } \\
\hline Brand Preference Pearson Correlation & 1 & .185 \\
\hline Sig. (2-tailed) & & .046 \\
\hline
\end{tabular}




\begin{tabular}{|c|c|c|}
\hline $\mathrm{N}$ & 100 & 100 \\
\hline Role of Media Pearson Correlation & .185 & 1 \\
\hline Sig. (2-tailed) & .046 & \\
\hline $\mathrm{N}$ & 100 & 100 \\
\hline
\end{tabular}

Interpretation: The above table indicate that Significant value is 0.046 which is less than $(\mathrm{P}<0.05)$, hence thenull hypothesis is rejected. There is a positive impact of media on brand preference.

\section{Experimental Results:-}

The average awareness of the respondents in the rural market is $74.70 \%, 70.3 \%, 72.02 \%, 64.1 \%, 72.7 \%$ in case of shampoo, washing powder, soap, tea, toothpaste respectively which infers that people in the rural market have on an average awareness about most of the products.

In the shampoo category the respondents give $1^{\text {st }}$ rank to pantene and last rank to Chik, to washing powder they gives $1^{\text {st }}$ rank to Surf excel and last rank to Nirma, While to soap the respondents give $1^{\text {st }}$ to Dettol, and last rank to Rexona, while to Tea they give $1^{\text {st }}$ rank to the Tata tea and last rank to Maharani tea and to toothpaste the respondents give $1^{\text {st }}$ rank to Colgate and last rank to Cibaca which infers that advertising and marketing activities have major influences in choices of people in rural market.

The respondents give $1^{\text {st }}, 2^{\text {nd }}, 3^{\text {rd }}, 4^{\text {th }}, 5^{\text {th }}, 6^{\text {th }} 7^{\text {th }}$ rank to quality, price, easy availability, family liking, advertisement, variety, credit attributes of brand preference respectively. It infers quality is the first preference in case of brand choices and rural people give least preference to variety and credit attributes.

Testing the hypothesis, it is found that male and female attitude towards the brand differs significantly. In other words, both gender categories have different attitude towards brand.

Consumers of different age groups have different attitude towards the brand.

Educational Qualification as one of the Categorical Independent variable also has a significant difference in terms of attitude towards the brand.

While, it is found that there is no significant difference among different income categories towards the brand of various FMCG products.

Hence, other than Family income all other demographic variables should be considered while designing brand quality, Price, advertising and sales promotion schemes more specifically cash discount. It is also concluded from the hypothesis testing there is a positive impact of media on brand preferences of FMCG products among consumers.

\section{Conclusion:-}

The brand awareness in rural areas particularly in respect of beauty care and health care products is showing an increasing tendency. (Most of the people both from illiterate \& literate groups prefer branded products with the belief that quality is assured as the manufacturers are reputed companies. For Ex: Colgate Tooth Paste, Head \& Shoulder shampoo).

People are not worried about the price of the product. They are showing willingness to spend higher price when they realize that they can afford to spend. Since the usage of branded products of reputed companies will elevate their status as well as stature in that village.

This change in the attitude to spend more on the highly priced branded products (Example: Dove Soap, Garniour Hair Oil) among high income groups in rural areas clearly suggests that there is an ample scope for such products to capture the markets in this areas by increasing the supply of these products.

The marketing agencies are advised to conduct health awareness programs by educating the people about the need to use the health care products to arrest tooth decay, hair fall, dry skin, etc. These products can be made more popular 
and acceptable among the rural people.

\section{Future Scope:-}

For The Researchers:-

The present research has considered FMCG products to measure the brand awareness and customer preference towards brand perception. For, other than FMCG products this type of research can be performed. This research has taken limited number of demographic variables as independent variables therefore considering more demographic variables; aspiring researches can conduct the research and may come out with interesting relationship. Further research can be conducted at the national level as this research has been conducted at the Rajasthan state level.

Brand quality, Price, Easy availability, Family liking, advertisement, variety and credit attributes have been taken as variables for the measurement of Brand perception in the study. Adding more variables to this further study can be conducted.

\section{For The Managers:-}

It can be referred from the findings that Brand preference is not the same across demographic variables. This offers the immense scope of segmenting the market based on customer preferences and designing the marketing strategies according to the target market, more specifically sales promotion strategy. There are various attributes as well attribute levels which should be considered while designing the promotion schemes. From the research study, managers can refer the important attributes and their levels which are important and preferred according to the consumer while responding to the promotion scheme to achieve the efficiency and effectiveness of the sales promotion schemes. In today's market scenario, consumers are bombarded with similar monotonous promotional messages, so managers need to design schemes, which will break through the chaos \& create the necessary impact. This study may provide the useful information in the direction of designing the clutter breaking sales promotion schemes to managers. Also the importance of the role of media came out clearly in this research.

\section{References:-}

1. Keller, K. L., Heckler, S. E. Heckler \& Houston, M.J. (1998)

2. Laurent, G., Kapferer, J. N. \& Roussel, F. (1987) Philip kotler, Koshy, Jha Marketing management.

3. William G .Zikmund: Business Research Methods

4. Hoyer, W.D. \& Brown, S. P. (2004)

5. Michael J. Zenor :The profit benefits (1994)

6. Rao, S. L. (2001). The Rise and fall of Fast Moving Consumer Goods (FMCG)-A Marketing Story.

7. The journal of consumer research 17(2), 141-148.

8. Abhisek Malhotra (2010), -The future of FMCG\|, Strategist Team /November 29, 2010, 0:03 IST.

9. Beverland, M. 2005. _Brand Management and the challenge of authenticity',Journal of Product and Brand Management, 14 (7): $\overline{4} 60-461$ www.socialsciences.com 